DOI: 10.20472/IAC.2018.041.006

\author{
MIHOVIL ANĐELINOVIĆ \\ Faculty of Economics and Business, University of Zagreb, Croatia \\ ANA PAVKOVIĆ \\ Faculty of Economics and Business, University of Zagreb, Croatia \\ LIVIJA VALENTIĆ \\ Faculty of Economics and Business, University of Zagreb, Croatia
}

\title{
EQUITY FUND PERFORMANCE AND SECTOR DIVERSIFICATION
}

\begin{abstract}
:
This paper examines the performance of equity funds relative to the diversification of their portfolios. The main objective of the research is to determine how the allocation of investment in individual sectors affects the yield of equity funds in the Republic of Croatia. Six equity funds which were selected, invested more than $50 \%$ of their assets in sectors in the Republic of Croatia. An unbalanced dynamic panel model is estimated for the period from January 2012 to August 2017. Investing in tourism and industry has proved to be the most significant investment and it has a positive effect on the fund yields, whereas significant negative impact has been discovered in consumer goods, funds and conglomerates and the state sector. The macroeconomic environment was studied in order to put the conclusions of econometric analysis into the actual context. The conducted empirical analysis suggests that portfolio managers should pay more attention to macroeconomic conditions and trends in economic sectors if they want to achieve higher returns.
\end{abstract}

\section{Keywords:}

asset liability management, equity funds, sector diversification, panel data model, Croatia

JEL Classification: C33, G11, G23 